\title{
Sustainable Environment, Economic Growth And Poverty Eradication Measures: The African Context: Why There Is No Meeting Point?
}

\author{
Dr Samuel C Dike ${ }^{1}$ LLM, PhD
}

\begin{abstract}
Poverty and hunger are the gravest challenges facing the African continent in the $21^{\text {st }}$ century. About One third of African population live below the United Nations poverty line of 1.5 dollars per day .Most African governments are struggling with poverty, epidemics, hunger, famine, insurgency, domestic conflicts and poor governance of both human and abundant natural resources found in Africa. However, some African states are well endowed with human and natural resources but are equally enmeshed in wars, ethnic conflicts and resource curse. Majority of African population would prefer poverty eradication measure, at any cost, over environmental sustainability measures. This is because, hunger and epidemics face most Africa states with agonizing contempt.However, there is a genuine desire by most responsible African leaders and governments to eradicate poverty and to catch up with the developed west, with minimal cost to the environment. This desire, sometimes, brings these African States into collision course with not only their natural environment but also against some basic fundamental objectives of modern global institutional frameworks for sustainable economic development.

Drawing from a socio- cultural perspective, and considering the level of poverty among some selected African states, this paper seeks to develop a mechanism for balancing economic growth with environmental sustainability in Africa. The methodology includes a discourse on some selected African states against the background of their existing policies and legal frameworks on economic sustainability.The significance of this paper is that an understanding of the impacts of the socialcultural backgrounds of the economic and environmental sustainability practices in these selected African states, may throw more light on why there seems to be no meeting point in Africa, between environmental sustainability practices and poverty eradication measures in Africa. The paper will recommend ways on how this balance could be achieved.
\end{abstract}

Keywords: environmental sustainability, economic growth, poverty eradication and Africa.

\section{Introduction}

The main thrust of this paper is to discover the missing link among environmental sustainability, economic growth and poverty eradication in Africa. The paper seeks to unravel the measures or framework that promotes a synergy and possible meeting points among the trio concepts. The objective is to ensure that poverty eradication frameworks are not antienvironmental sustainability focus and that African leaders can develop the continent, promote economic growth without jeopardising their environment (UN Declaration 1972).

It is certain, that African countries have been committed to developing an effective response to the challenges of environmental sustainability and poverty eradication. This is through the New Partnership for Africa's Development (NEPAD), which was launched in 2001 and which provides a framework for sustainable development to be shared by all Africa's people (NEPAD 2001). NEPAD emphasizes the role of partnerships among African countries and the international community while promoting a shared vision to eradicate poverty through sustained 
economic growth and sustainable development.

Historically NEPAD precedes such initiatives as the Lagos Plan of Action (1980), the Final Act of Lagos (1980), Africa's Priority Programme for Economic Recovery (1986-1990), the African Alternative Framework to Structural Adjustment Programme (1989), the African (Arusha) Charter for Popular Participation and Development (1990), the Abuja Treaty (1991) and the Cairo Agenda (1994). Others are Millennium Africa Recovery Plan (MAP), 2001 Omega Plan, pioneered by Senegal, Abdoulaye Wade, 2001. Both MAP and the Omega Plan gave birth the New Partnership for Africa's development ( NEPAD in 2001) The objective was to have an African plan and vision for sustainable economic development which is culturally relevant to meet African diverse needs. This cultural peculiarity of the Africa's economic growth principles seemed to be anti environmental sustainability, hence the objective of this paper is to unravel why it should be so.

The methodology adopted in this paper is to select randomly some African states and some major indicators of development based on available data. The African states chosen as in this paper are those that have shared experiences in the areas of environmental sustainability and whose citizens, are passing through phases of poverty. The author shall conclude that there is a wide gap between environmental sustainability and poverty in Africa and this gap has occasioned unsustainable development; stating that unless environmental sustainability is factored into most of the poverty eradication measures in Africa, through effective legislative and administrative frameworks, beyond policy statements, economic growth that is sustainable will continue to elude some African states.

The author will also examine the reasons why African states do not fully apply the spirit and the letter of environmental sustainability principles in Africa and it will make relevant recommendations. The significance of this study is an understanding that African leaders and government are prepared to embark on sustainable economic development but hampered by both internal and external factors. Consequently, there is a need for collaborative initiatives between Africa and the rest of the world as the lack of adequate enforcement of critical environmental sustainability practices in one continent, may promote man-made or natural disaster such as flooding in another country or continent (UN Declarations 1972). This failure may further contribute to serious cases of refugees, poverty and migration of people from the disaster -prone continent or zones to safer continent (Nepal 2015). This why the author addresses the essential linkages and interfaces among poverty eradication, economic growth and environmental sustainability.

Also, the author endeavours to unravel some peculiar developmental challenges facing Africa, such as food crisis, population and geographical factors, poverty, hunger and epidemics, corruption and weak institutions, poor agricultural and land and energy use practices and the poor management of climate change scenarios (Boko, M. et al). Other external factors, such as international trade and globalisation, foreign aid practices and multilateral financial institutions, which also affect African States' economic and environmental practices, would be examined.

In order to achieve the purpose of this paper, it shall be divided into five parts namely (1) Introduction (2) analysis of selected African States' sustainability and economic growth initiatives (3) factors affecting the African States' style of environmental sustainability and economic growth (4)Recommendations (5) and conclusions. As part of the authors finding, it will recommend an integrated and consistent approach for economic growth, environmental protection and poverty alleviation. 


\section{Selected African States And Problems That Affect Sustainability And Economic Growth.}

Africa is bounded by the red sea and Suez Canal in the North East, the Atlantic Ocean on the West, the Indian Ocean on the South East and lies within the gulf of Guinea. Africa has one of the world`s largest deserts. The continent occupies a total land mass of $11.7 \mathrm{~m}$ square meters and traverses various climate variations. Although, Africa is the second largest continent in the world with a population of over 1.1 billion People.( World Atlas 2015). The continent is blessed with abundant natural resources like gold, bauxite, uranium, hydrocarbon and, diamond, just to mention but these. The continent is also has adequate human capacity as a result of rising population growth. Both natural capital of the earth, solar, wind, water and hydrocarbon, are evenly distributed within the continent. It has both arid, semi -arid regions and the only continent that cuts through the North and South poles. This is a source of strength as well as vulnerability to the climate change risks, which affect the sustainable development of the continent (UNDP 2014).

Amidst these potentials, African continent still lag behind in terms of attainment of Human Development Goals and poverty eradication. Epidemics and diseases like HIV/AIDS, malaria, poverty, hunger, inadequate access to safe drinking water, poor sanitation and lack of other basic things of life, are highly prevalent in most African states more than anywhere else (United Nations 2014). Poverty and hunger are greatest challenges to environmental protection and economic development in Africa (World Bank 1990). For the poor and the hungry would face the reality of uneconomic development and are more vulnerable to environmental risks like pollution, climate change and unsafe drinking water, dislocation of homes caused by flooding and epidemics. The poor has no adaptive capacity for resilience to climate and environmental risks (John 2008)

Poverty alleviation and environmental sustainability are functions of economic growth (World Bank 2015). There are several factors that affect poverty and growth level in Africa but the growth elasticity in Africa is underpinned by the absence of a diversified economy, poor access to credit and insurance, low human and physical capital and weak systems of social protection by governments. However, investment in modern agriculture and diversification of the economic bases are considered antidotes to poverty given that three-quarter of the worlds poor are rural farmers (Xinshen Diano et al, 2007). Other factors are economic liberalization, inadequate capital, lack of up to date technology, foreign aids from developed nations, lack of good institutional governance, improper education and information dissemination (John 2008). Other African states are ravaged by internal political disorder, inept corruptive leadership, and local conflicts and these have negative implications to economic growth and environmental sustainability.

On the prevalent of poverty despite minimal economic growth, the UN report maintained that: High mineral and fuel-commodity prices have driven growth in many of the African countries that have recorded the fastest growth, such as Equatorial Guinea and Nigeria.... Thus the large rural population, lacking adequate access to physical and social infrastructure, is a major impediment to reducing poverty and inequality (Angela 2014) (United Nations Progress Report2014).

The United Nations Report titled "Assessing progress in Africa towards the millennium development goals: emerging perspective from Africa on post 2015" stated that Goal 1: on the eradication of extreme poverty and hunger is off track: $\$ 1.25$-a-day poverty in Africa, while on Goal 7, on environmental sustainability, is facing the challenge of deforestation leading to loss of forest cover and vulnerability to climate change risk". It is apposite that environmental sustainability has a knock -on effect in attaining other MDGs, particularly poverty eradication.

Similarly, climate change risk is ravaging the African countries and the continent is most 
vulnerable to climate change risk due to poverty. The poverty situation contributes to its low capacity to respond and adapt, to climate change risk. However, it is also true that the continent emits quite little greenhouse gas relative both to its population and to other regions (Boko M, et al 2007). The negative impacts of Biodiversity, desertification, erratic rainfall, higher temperatures and water scarcity in Botswana, Malawi, Mozambique, Zambia and Zimbabwe are well noted. Agriculture's expansion into marginal lands has deforested large tracts of land, affecting water tables. Thus, addressing climate change risks in some African states and ensuring climate-resilient development through adaptation and mitigation have become priorities for governments and development agencies in recent times.

African forest cover is given away due to the dependent of the poorer population of Africa on the agricultural sector. This in turn leads to poverty, as most rich agricultural vegetative cover is lost leading to poor yields and low export (Xinshen Diano 2007). For the hydrocarbon dependant African states such as Nigeria, Angola and Chad, gas flaring, which promotes green house gas effect contribute to climate variability( Environmental Action Group/Climate Justice 2005), (Omorogbe 2008). This in turn affects the poor African population that do not have the expertise to develop adaptive responses to climate change risks (Coulibay 2015).

Similarly, most African countries had been enmeshed in decades of conflict over resource ownership and mismanagement and this has contributed to poverty (Moller 2011). The Nigerian Civil war of 1970 ,was fought because of the need to control oil which was found in the eastern part of Nigeria and the war promoted poverty and unsustainable development rather than growth (Muzan 2014). The Republic of Congo has been entangled with decades of war and civil strife due to the problem associated with the control of mineral resources (Burnley 2011). The same scenario led to the splitting of Sudan into Southern Sudan from Sudan, but before then, millions have lost their lives due to internal conflicts over the right to control hydrocarbon resources (Burnley 2011). Lybia, Egypt had had their fair share of conflicts over the mismanagement of natural resources by their past leaders but are presently enmeshed with insurgency, terrorism and slow progress, which have negative impacts or sustained growth principles.

Only recently, Ebola, deadly virus, almost swept off some West African states like a Tsunami but thanks to global partnership initiatives and the resilience of some African governments. Some sub-Saharan African states such as Liberia, Sierra loan are still reliving the orgy of Ebola virus in these countries ( Centre for Disease Control and Prevention 2014). These situations have negative implications on sustained economic growth which mainly depends on human capacity to thrive unlike the developed west, where technology, rather than human beings, drives most of economic growth.

Consequently, the resultant impacts are poverty, disease, epidemics, migration, refugees and hopelessness of majority of the population. It could thus be argued that these African governments could justifiable be busy with reconstruction, rehabilitation of the lives of their deprived citizens and endeavouring to place priority on human development rather than environmental sustainability. This is because, environmental sustainability may be considered cost intensive in the short term and what these states need most is the eradication of hunger and the protection of the lives of their citizens from deadly disease and famine.

In order to demonstrate their willingness to address economic growth, poverty eradication and environmental sustainability, most African states, like some developed nations, have also ratified and adopted the United Nations Millennium Development Program and participated and or ratified the United Nations Declaration on Human Environment (UNEP 1972) United Nations Environment and Development, (UNEP 1992), Convention on Biodiversity, (UN 1992) United Nations' Framework Convention on Climate Change (UNFCCC 1992), Convention on the prevention of pollution of the marine environment by dumping of waste and other matters 1972 and Internal Human Rights conventions, just to mention but these few. 
The other objectives for embarking on this step are to promote economic development and living standards of their citizens through global partnership (Gordon and Wage 2010). Unfortunately, some of these global norms are mere declaratory, non binding and some, have not been fully domesticated into the national laws of African countries. (Walde 2004). It is argued that a Treaty, once domesticated, by national governments, should affect the way of lives of members of the participating country (UNDP 1992). However, it is now clear that incorporating global norms into a country's legal code and actually practising them in principle are entirely two different scenarios as shown by the practices in most African states due to their peculiar economic and social circumstances. (Ladan 2015).

Thus, it could be argued that preserving and properly managing the environment is an essential foundation for sustainable development and poverty reduction. However, some African countries are demonstrating commitment to environmental sustainability; many of them are hampered by lack of political will, pressure on environmental resources to support economic growth, weak governance and planning frameworks, and the lack of financial resources (Omorogbe 2008). Consequently, remarkable advances have been made in some areas, much still need to be done to achieve all inclusive sustainable economic growth (African Union 2014) and ( UN MDG progress 2014).

The first millennium development goal is on the eradication of extreme hunger by 2015 and eight millennium development goals is on ensuring environmental sustainability. The author argues that these goals are anything but achievable in some African states (United Nations MDG Progress 2014). In order to appreciate the peculiarities of African problems vis-avis environmental sustainability, the author examines the impact of food security/crisis, population and demographic issues, war, epidemic factors, energy uses and some external factors like globalisation, foreign aids and debt relief measures of multilateral financial institutions as they affect Africa.

\section{Food Crisis And Environmental Sustainibility}

Food crises affect environmental sustainability practices and poverty alleviation in some African states. According to World Bank World Development Report 2010, all African states are vulnerable to food crisis, poverty, and hunger (World Bank 2010). From Nigeria to Ethiopia, Zambia to Angola, Libya, and Kenya to Somali, the story is the same. The importance of adequate food supply, improved standard of living cannot be over emphasised. The global scenario on food supply is disturbing. The availability of feed stock in the world does not mean that everyone is well fed. Out of the 850 million people who are hungry worldwide, 800 million of these are in developing country chiefly in sub Sahara Africa (UN F00D 2005). About one third of the population of sub-Saharan Africa is malnourished. Majority of them are women and children (Kofi Anan 2002).

As food supply, hunger and poverty are primary in African states; the desires of some African leaders to pursue efforts that will enable them put enough food on the table of their deprived population, raise their standard of living, and have been considered primary needs. To African leaders, it could be argued that living sustainably means that the hungry population should be fed first at all cost. It does not matter whether such cost would compromise the carrying capacity of the environment or whether such decision failed to factor in environmental costs.

A good example is the use of genetically modified chemicals to improve crops yields, which contribute to environmental degradation in the long run (Asthana and Asthana 1998). This is because the use of chemical brings with it some negative impacts on agricultural lands which are the main capital needed by the present and future generations to grow (Blewith 2015). However, the African states that depend on commodity exports are forced by trade distortions to 
compromise best international practices by employing unsustainable means to satisfy their importing developed markets since the tendency is to grow more food. This is the main collision with the principle of sustainable development. Poverty and lack of food requirement are therefore major barriers to the effective implementation of the principle of sustainable development.

\section{Population/Geographical Factors}

The growing level of African population contributes to poverty and lack of environmental sustainability. This is because, while African population is rising by geometrical progression, economic growth to meet the spiral population is nose-diving steeply (African News 2009). African population is over 1 billion and is the second largest continent following Asia. Population has effect on life style and economic activity, so also geography has influenced on economy and poverty. Population pressure and high cost of oil are increasing the demands for traditional fuel in the developing countries of the south (John 2008). Nigeria, for instance, has a population of about 171, million people (Gordon and Waaga). Out of this number, only about 47 $\%$, enjoys life expectancy at birth (World Bank 2008).

In $2006,46 \%$ of the Kenyan population was unable to provide her basic food and non- food requirements. Ethiopia and Nigeria have presently uncontrollable birth rates and if nothing is done to curtail their spiral population growth; it will be difficult to implement the principle of Sustainability. None of these African states has any improved GDP, a better life expectancy arising from improved food supply.

However, Principle 8 of the Rio Declaration, provides that "in other to achieve sustainable development and a higher quality of life for all people, states should eliminate unsustainable patterns of production, consumption and promote appropriate demographic policies". (UN Declaration 1992). Thus, a sizeable population can be managed economically and hence divert better attention to other social factors like quality education, standard health care, and developed technology. African population today is a barrier to the effective implementation of the principle of sustainable Development because of the need to eradicate poverty.

The location of African states in terms of Geography brings mixed benefits. Most African states have access to the seas, arable land, biological biodiversity and temperate climate. These, however, contribute to a pattern of development and poverty. While some African states are located in semi arid region, except those in the North Africa, they are yet to tap from the rich deposits which their geographical location provides. Some African states such as Libya are facing serious drought, deforestation and desert encroachment while places in South and Western Saharan like Nigeria, and Bostwana are faced with erosion desertification and depletion of resources due to environmental degradation.

It is also easier to develop plain land than mountainous location on deltaic land. A tropical climate breeds diseases such as malaria and other vector parasites. Malaria is a scourge which affects the working population in Africa. In Kenya, Nigeria, Somali, Libya, so much efforts had been wasted by their governments in addressing malaria- related diseases. This wasted effort should have been transferred to the effective implementation of the principle of sustained nation building. Malaria is the main cause of infant mortality in Kenya, Nigeria, and Somali (Jeffery 2007).

\section{Energy Development And Sustainibility In Africa}

How a nation deploys its energy sources affects sustainable development and economic growth. African countries are blessed with abundant natural capitals like crude oil, bauxite, diamond, gold, natural gas and ore. However, $80 \%$ of African energy sources come from Biomass such as fuel wood, charcoal and animal dung. This affects a forestation, carbon retrofit and 
environmental sustainability. This is because wood-crops are required for the growth of biomass energy and the later is relevant in protecting the climate. (Elen Kebede 2010). Achieving a higher access to energy services in Africa is a challenge to the people.

Energy use also affects such areas as water supply, education, healthcare, agricultural and land use. Wind energy, tidal, and nuclear energy are yet to take off steadily in most African states. Most African states also depend on hydrocarbon for their export earnings and in meeting economic growth. Consequently, their natural environment are rather destroyed or damaged in Africa than preserved due to the desire to satisfy the food and economic empowerment of their African population. For instance, crude oil located in green fields or green verges must be explored in Nigeria, at all cost, to the environment due to the priority the government places on this sector (Dodowa 2014).

Similarly, the continuing acts of gas flaring by the petroleum industries in Nigeria, despite the international condemnation of this dastardly act, goes to show the nature of the Nigerian unsustainable petroleum industry practices. This is done in complete disregard to wide rage of international best practices, which would reduce gas flaring. The fact that no concrete legal regime has been developed to end gas flaring in Nigeria and Angola makes the industry unsustainable( Gas flaring Prohibition Act 2009).Similarly, in Congo, South Africa, Angola and Somalia, and some other Southern and Eastern African states, the extraction of or the mining of diamond and bauxite have compromised the environmental sustainability and best practices due to lack of diversified economic activities and the total dependant of these countries on these sectors (Blewith 2014).

Again, the distribution and the poor management of wealth from natural resources such as oil, bauxite, gold diamond, natural gas, which abound in Somali, Nigeria, Angola. Kenya, Chad Congo, Somalia and Sudan, had also engendered military rule, ethnic militia, insurgency and terrorism due to misrule and corruption. These factors ultimately lead to unsustainable economic growth, resource curse and poverty. (Havro and Santison 2011). Therefore, decoupling the benefits of natural resources endowed in African states from the negative effect of poverty, civil strife have more than anything else, occupied the attention of African leaders than the abstract concept of sustainable development.

The International Energy Agency, has consequently predicted that by 2030, $70 \%$ increase energy demand will come from the developing countries and the rest $30 \%$ by the developed west would grow richer (WEA 2004). The implication of this is that the high energy demand in Africa would make global energy market competitive and countries with inverse terms of trade in Africa would be disadvantaged. Therefore, I will argue that the energy uses and forms in Africa contribute to poor environmental sustainability.

\section{Consumption Pattern, African States And Sustainability}

The principle of sustainable development is synonymous with a regulated consumption pattern. Poor and unregulated consumption pattern in Africa affects environmental sustainability and economic growth. The use of second hand cars and electricity in developing African states can be anything but sustainable. Some of the third hand-colloquial words ( for used vehicles in Nigeria), had been in use in the developed western nations like Germany and Japan for decades before been shipped to African states .Most of these vehicles have been found unserviceable and pollution laden. However, they are relatively cheap and affordable to the poor who may not afford the price of new vehicles. However, these cars contribute to environmental pollution through the emission of green house gas that leads to climate change.

The same scenario applies to agricultural land in some North African countries where grass lands are overgraze to feed their cattle that supply proteins as there is no alternative means for protein 
supplement to their population. This is what is regarded as the tragedy of the commons by Garret Harding, as more population would suffer in the long run due to less regard for sustainability (Harding 1968).

\section{Wars, Insurgency, Corruption And Sustainability}

There cannot be a consistent environmental sustainability programmes in the midst of wars and insurgency. Many African states are bedevilled with one form of conflict or the other due to governance challenges. Similarly, wars, ethnic insurgency and terrorism and corruption have been the bane of the African continent. It has been stated that $90 \%$ of wars occurs in less developed countries some of which are in Africa (John 2008). These factors contribute to the unsustainable form of development in the continent.

These problems are accentuated by their corrupt leadership, who promote, corruption, ethnicity, tribalism, gender inequality and mediocrity in place of meritocracy (UN ${ }^{2015)}$ These factors are partly responsible to the poverty growth level in the continent and resulted into diseases, hunger, epidemics and death of countless African populating in some of the war ravaged African countries like Somali, Congo, Sudan, Chad, Nigeria, Angola and Libya. Most of the leaders of these countries are busy reconstructing and rehabilitation their societies and ensuring poverty eradication; hence placing priority on human development above environmental sustainability. There is therefore improper management of natural resources in Africa due to these challenges and this affect economic growth (Moller 2011).

\section{Climate Change Risks And Environmental Sustainibility}

The African continent believes that climate change risk is a product of industrialised western countries. Consequently, it has been a herculean task to get African states to effectively participate in measures that would reduce green house gas, thus exposing the continent to climate variability (Barnet 2004). The Kyoto Protocol seemed to have lent support to the posture put up by the African states. This is by failing to give the developing countries any responsibility under the Protocol. The author argues that a common but differentiated responsibility which captures the little contributions of developing African states to climate change risks, would have spurred them to lead the campaign to environmental sustainability and acceptable growth pattern. This more so, as land use and deforestation also contribute to emission of carbon and other green house gasses (Boko, M. et al, 2007).

Most of the African governments are therefore not strengthened to participate in clean development programmes and other multilateral environmental agreements due to their nonchalant attitude to environmental sustainability principles. However, the threat of climate change and its attendant problems would-be felt more in developing countries of the world than the developed west. For this reason, it is suggested that every nation be given proportional target to cut emission and no nation be exempted for the flimsy reason of their poverty levels.

\section{External Trade/ Foreign Aid African States, And Sustainable Development}

It has been noted that the term of trade under the international law does not favour the African states (African Commission Report). This is due to the fact that African export market is dominated by a commodity market and the importing countries will grant subsidies to western markets and producers but will not support similar subsidies to be granted to locally produced goods in Africa. Therefore, in order to produce commercial brand of goods to meet the needs of their importers, genetically modified crops are produced through bio-technological means. This is 
ultimately an unsustainable practice in the long run due to their negative impacts on land and agriculture. These genetically modified chemical crops do not meet the quality and standards of those produced in Europe and other western countries, hence the loss of foreign exchange and this contributes to poverty of the African population. Apart from this, chemical produced foods are less nutritious than the organic produced food.

Similarly, due to over-dependence on primary commodities, growth in Africa over the past decade has been non-inclusive and volatile and trade barriers are inequitable against the African continent. The same goes to foreign aid and debt relief measures granted by various multilateral financial institutions such as World Bank as some conditions attached to debt relief by western countries and donor agencies, are not pro-poor but are tied to certain capital projects that do not deal with human development in most African states. Various attempts to repay these foreign debts by some Africans countries have drawn them into the orgy of poverty and domestic conflict.

\section{Recommendation}

The African state should reduce population growth in line with their economic capability. They should also adopt innovative technology, educational knowledge and capacity that are required to march on with environmental growth demand by their industries' uptake. Further, African leaders and the people together should address corruption and mediocrity in dealing with the economy and their citizens, thereby reducing wars, strife which are rampant in the continent . They should also protect the ecosystem by adapting to improved agrarian economy which will reduce dependence on monolithic oil, gas or diamond or energy intensive sectors. The leaders should encourage global partnership in the area of poverty eradication and environmental sustainability and African states should liberalise their economy by adopting upto- date technology and best international business practices peculiar to their environment in poverty eradication, environmental sustainability and economic growth. As African poorer population would be most vulnerable to climate change risks, the African government should strive to develop adaptive responses and mitigation measures to address climate change problems; land use, deforestation and gas flaring. This should be so whether there is any clear responsibility or binding target from the international community. Finally, African states should, in a clearly defined approach, incorporate sustainable development in their domestic laws (whether as soft or hard laws), as this is good for environmental sustainability and poverty eradication .Finally, all trade barriers questionable tariffs and distortion that negatively affect the African states should be removed and debt relief measures that affect African states should have human face or more propoor.

\section{Conclusion}

This paper has been able to explain the concept of environmental sustainability, poverty eradication and their interactions with economic growth from the African perspective. The paper considers the role played by food security, population and demographic matters, wars insurgency and diseases climate change risks, external trade and debt relief measures in sharpening the African style of environmental sustainability. It concludes that there is the need for a reorientation in order to attain a sustainable economic growth. The paper concludes that unless there is a change of style and modus operandi in this regards, poverty eradication measures due to advanced economic growth, would continue to elude some African states and this is with adverse consequences to environmental sustainability.

The author concludes that a critical appraisal of the above factors would help to ensure a meeting 
point among poverty eradication measures, environmental sustainability and economic growth principles in Africa.

\section{References}

Declaration on Environment and Development ( Rio dejaneiro,3-14 June 1992 ) UN D/ Doc.A/CoNF.151/PC/L.31 Annex (1991) See in particular Principle 3.

NEW Partnership For Africa's Development (NEPAD )2001 “About NEPAD” ( 2010-2012 )< http://www.nepad.org/about> accessed 29 4/2015.

NEPAD < http://www.nepad.org/history > accessed 21 May 2015

United Nation Commission on Economic and Social Affairs, 'Sustainable development; shared knowledge $<$ https://sustainabledevelopment.un.org/topics/Africa > accessed 14 April 2015

Boko, M., Niang .I, Nyong .A, Vogel .C, Githeko .A, Medany .M, Osman-Elasha .B, Tabo .R , \& Yanda .P, : Africa Climate Change 2007: Impacts, Adaptation and Vulnerability. Contribution of Working Group II to the Fourth Assessment Report of the Intergovernmental Panel on Climate Change, in Parry .M.L, Canziani .O.F, Palutikof .J.P, van der Linden .P.J, \& Hanson .C.E, Eds., Cambridge University Press, Cambridge UK, $\quad 433-467<$ https://www.ipcc.ch/pdf/assessment-report/ar4/wg2/ar4-wg2-chapter9.pdf> accessed 15 April 2015

World Atlas, 'Africa Overland the safari'< http://www.worldatlas.com/webimage/countrys/af.htm $>$ accesed15 April 2015

United Nations Human Development Report 2014, "Human Development Index"

$<$ http://hdr.undp.org/en/content/table-1-human-development-index-and-its-components. $>$ accessed 29 April2015 . Apart from Algeria, Tunisia and Ghana the rest African countries appear under or have low human development index .Poverty, illiteracy, malnutrition, are prevalent in African states more than anywhere else in the world .

United Nations, MDG Progress Report, Assessing Progress in Africa Toward the Millennium Development ( 31 October 2014) < http://www.undp.org/content/undp/en/home/librarypage/mdg/mdgreports/africa-collection.html> accessed 29 April 2014.

World Bank, World Development Report 1990

NEPAL 'Help The Victim of Nepal '< http://edition.cnn.com/2015/04/25/world/nepal-earthquakehow-to-help/index.htm18 May 2015, accessed21 May 2015.

John Seitz, Global Issues :An Introduction ( $3^{\text {rd }}$ Ed Edition, Blackwell 2008)10-14

World Bank," Poverty Overview" (2015) < http://www.worldbank.org/en/topic/poverty/overview> accessed 29 April2015.

Angela Ruler USAID:Frontline," The End of Extreme Poverty" ( $2^{\text {nd }}$ April 2014 )< ://blog.usaid.gov/2014/04/frontlines-the-end-of-extreme-poverty/> accessed 7 May 2015.

Xinshen Diao, Peter Hazel, Danielle Remsic and James Thurlow, "The Role of Agriculture in Development: implication for sub Saharan African" (2007) 153 International Food Policy Research Institute Report 19-20

Environmental Right Action /Climate Justice, 'Gas Flaring in Nigeria: A Human Rights, Environmental and Economic Monstrosity (Netherland, 2005)1-5www.Eraction.org accessed 4 April2013and <www.climateLaw.org > accessed 4 April 2013.

Yinka Omorogbe, Promoting Sustainable Development through the Use of Renewable: The Role of Law' in D Zillman, C Redgwell, Y Omorogbe and L K Barrera Hernandez' Beyond the Carbon Economy: Energy Law in Transition (OUP 2008) 45- 46.

COULIBALY Jeanne Y.; Mango, Joash; Swamila, Martha; Tall, Arame; Kaur, Harneet;Hansen, James, “What climate services do farmers and pastoralists need in Tanzania? Baseline study for the GFCS Adaptation Program in Africa (2015) CGIAR Research Program on Climate Change, Agriculture and Food Security (CCAFS) 1-5

Allswell Osini Muzan, Insurgency in Nigeria: Addressing the Causes As Part of the Solution (2014) I African Human Right Law Journal 221.

Clementine Burnely, "Natural Resources Conflict in the Democratic Republic of the Congo: A Question of Governance" 12 nos 1 (2011)7-11-52-53 
World Atlas, Africa (April 29, 2015) < http://www.worldatlas.com/webimage/countrys/af.htm> accessed $29 / 4 / 15$

World Health Organisation, Current Situation: Cases in the Most Affected Countries Ebola, “ $<$ http://apps.who.int/ebola/> accessed 5 may 2015.

Declaration of the UN Conference on Human Environment, Stockholm,5-16 June 1972 UN Doc.A /CONF 48/14/REV.1.

See for report Declaration of the UN Conference on Environment and Development Rio de janeiro 3-14 1992, UN Doc A/CONF.151/PC/L.31 Annex(191). 31 ILM 1992

UN Doc. A/CONF.151/8 Nigeria adopted or ratified the International Human right order based on section 12 of the 1999 Constitution, and it also adopted the African Charter 31 August 1982 and 22nd June 1983 on Human and Peoples Rights.

Gordon Conway and Jeff wage, Science and Innovation for Development (Development for International (2010) $107-116$

T W Walde 'The Role of International "Soft Law" in Natural Resources and Energy' (2004) 2 (4) OGEL 24

UN Declaration on Environment and Development Rio dejaneiro 3-14 June1992, Un Doc.A Cof $151 / \mathrm{pc} / \mathrm{L} .31$

M T Ladan, 'Policy, Legislative and Regulatory Challenges in Promoting Efficient and Renewable Energy for Sustainable Development and Climate Change Mitigation in Nigeria' http://www.safesearch.net/search?q $=$ renewable + energy + support + regimes + in + nigeria $+\& o=10$ Accessed on 10/3/2015

African Union, 'Common African Position on the Post UN 2015 MDG Agenda' (March 2014) $<$ https://sustainabledevelopment.un.org/content/documents/1329africaposition.pdf $>$ accessed 14 April 2015.

World Bank, "World Development Report 1990 Poverty" (New York: Oxford University press, 1990), P2 Half of the world's poor lives in Asia and Africa particularly the sub Sahara Africa.

UN Food and Agricultural organization: The state of Food and Agriculture (2005) World and Regional Review at< www.fao.org.> p117-119 accessed 15 May 2015.

Kofi A nnan (2002): The Role of the United Nations in the 21st Century(New York, United Nation2001)N099 cited in John L Seitz, Global Issues :An Introduction(3 ${ }^{\text {rd }}$ edition Blackwell's 2008)P.13

Guardian publication, All African .com. Dec 2009.

D K Asthana and Meera Asthana, Environment: Problems and solution ( S. Chand and Company Limited 1998)130-131.

John Blewith, Understanding Sustainable Development ( Routledge 2015) 73.

African News < Http:/www/global issues.org/article/poverty-fact states (August 25, 2009).

Gordon Canway and Jeff wage, , Science and innovation for Development (UK Collaboration on Development Sciences and For International Development 2010)63-75.

World Bank world Development Indicators 2008-12 <www.world bank.org/environment/data> accessed on17-7-2010.

Royal Geographical Society, "What is Geography " < http://www.rgs.org/geographytoday/ what+is+ geography. htm> accessed 15May 2015.

Jeffrey D. Sachs, Ending Malaria Scourge in Africa (2007)297 Scientific American 42-44

Barry Muss low ,'The politics of unsustainable Development" (1999) 20(3) third world quarterly p.551-568

Africa Energy Situation, < http://www.desertec-africa.org/index.php?option=com_content\&view=category \&layout=blog\&id=2\&Itemid $=2>$ accessed 15 May 2015.

Ellene Kebede, John Kagochi, Curtis M Jolly, "Energy Consumption and Economic Development in SubSahara Africa" (2010)32 (1) Energy Economics533-535.

Abeeku_brew -Hammond, "Energy Access in Africa: Challenges Ahead" (2011) 38 (8) Energy Policy 22932295

Tunde Dododawa, “Nigeria at 54 Crude oil Discovery: What a manner of Blessing?” 9 Tribune (1st October 2014http://tribune.com.ng/business/tribune-business/item/17430-nigeria-54-crude-oildiscovery-what-a-manner-of-blessing/17430-nigeria-54-crude-oil-discovery-what-a-manner-ofblessing accessed 15 May 2015. 
Samuel Iyiola Oni and Mark Abioye Oyewola," Gas Flaring, Transportation and Sustainable Energy Development in the Niger-Delta, Nigeria”( 2011) 33 (1) Journal of Human Ecology 21-28.

Nigeria, the Anti Gas (Flaring and Prohibition) Act 2009, has not been passed into law after the failed efforts by the Associated (Gas Re- Injection) Decree 1984 with its amendment of 1985, failed to stop gas flaring menace in Nigeria.

John Blewith, Understanding Sustainable Development (Routledge 2015) 131

C Havro and J Santiso, 'Benefiting the Resource Rich: How can International Development Policy Help Tame the Resource Curse' (2011)355 Working Paper Institute of Development Studies 3.

World Energy outlook (WEA) 2004 p.64

Herding Garret, The tragedy of the commons' (Science 1968)1243, cited by Seitz (n)p273.

United Nations Economic Commission for Africa, Industrialisation through trade "African Economic Report 2015 “, Pages 7and 56.

Moller .L, 'The Governance of Oil and Gas Operations in Hostile but Attractive Regions: West Africa' (2011) International Energy Law Review 5-

Jon Barnett, Suraje Dessai, Michael Webber, 'Will OPEC Lose from the Kyoto Protocol' (2004) 32 Energy Policy 2077-2079.

Centre For Diseases Control and Prevention (13 May 2014), 'Ebola Out break in West Africa <http://www.cdc.gov/vhf/ebola/outbreaks/2014-west-africa/distribution-map.html accessed> 21 may 2015 